\title{
Assessment of climate change impacts on the water resources of Panama: the case of the La Villa, Chiriquí and Chagres river basins
}

\author{
Daly Espinosa*, Abril Méndez, Irina Madrid, Raúl Rivera \\ Instituto de Recursos Hidráulicos y Electrificación, Apartado Postal 5285, Panamá 5, Panama
}

\begin{abstract}
The goal of this study is to develop different scenarios of water resource availability in Panama under climate change-induced temperature and precipitation variability, considering a potential doubling of the atmospheric $\mathrm{CO}_{2}$ concentration in the next $100 \mathrm{yr}$. The water balance model CLIRUN3 was combined with 20 yr of basic climate information records (precipitation, potential evapotranspiration and water flow) to simulate monthly river runoff in the Chagres (Panama Canal) river basin. This basin supplies water to $25 \%$ of the country's population and is of great importance for international navigation. In the cases of the Chiriquí and La Villa river basins, 10 yr of records were used. The Chiriqui river basin is the main national source of hydropower, while the La Villa river basin is of agricultural importance. The Chagres river basin is part of the Atlantic watershed while the others belong to the Pacific watershed. The model was calibrated and run for both watersheds under scenarios with temperature increments of +1 and $+2^{\circ} \mathrm{C}$, while the precipitation changes considered were $\pm 15 \%$ for the Pacific and $\pm 20 \%$ for the Atlantic watershed. It was observed that the monthly runoff tends to decrease by 3 to $42 \%$ of the mean value in both watersheds when temperature increases and precipitation decreases. If both temperature and precipitation increase, the mean runoff value in the Pacific basins will be reduced by 5 to $35 \%$ from November to April and increased by 4 to $40 \%$ in the remaining months. In the basin of the Atlantic watershed all simulated monthly values are 3 to $50 \%$ higher than the actual mean.
\end{abstract}

KEY WORDS: Panama $\cdot$ Water resources $\cdot$ Climate change

\section{INTRODUCTION}

The Republic of Panama has abundant water resources. This fact determines to a large extent the economic activities on which the national economy is founded. Tertiary activities consisting of services and international trade are the main source of income for the country.

In this study, we set out to assess the impacts of possible future climate change on Panama's most important rivers. To select river basins suitable for study, both the relevance of their water resources for the country's economic development and the availability of hydrometeorological data were taken into account. The basins identified as the most significantly exposed

•E-mail: hidromet@panama.phoenix.net to the impacts of potential climate changes were the Chagres, the Chiriqui and the La Villa river basins.

The Chagres river basin, pertaining to the Atlantic watershed, covers a drainage area of $3338 \mathrm{~km}^{2}$. Annual mean precipitation is $2600 \mathrm{~mm}$, annual mean temperature is $25^{\circ} \mathrm{C}$, and the runoff coefficient is 0.58 .

The Chiriquí river basin pertains to the Pacific watershed. It has a drainage area of $1337 \mathrm{~km}^{2}$ upstream of the hydrological station used for the study. The mean annual precipitation in this area is $4280 \mathrm{~mm}$, the mean temperature is $23^{\circ} \mathrm{C}$ and the runoff coefficient is 0.75 .

The La Villa river basin, which is also located on the Pacific watershed, is considered one of the most arid regions in the country. It covers a drainage area of $1000 \mathrm{~km}^{2}$ upstream of the hydrological station. The annual mean precipitation is $1960 \mathrm{~mm}$, the mean temperature is $27^{\circ} \mathrm{C}$ and the runoff coefficient is 0.54 . 
The availability of water for domestic consumption, hydropower generation (on which the country depends for $73 \%$ of its power), irrigation, animal breeding and inter-oceanic navigation is important for the people's quality of life. A change in the climatic conditions would affect the water volumes required for the correct operation of the inter-oceanic waterway (Panama Canal). It would also impair the provision of services due to difficulties for hydroelectric generation and would provoke conflicts between domestic and agricultural water use. It was therefore considered necessary to assess the major impacts of a potential climatic change on the water flow of the main national basins.

The use of 20-yr data series for precipitation, potential evapotranspiration and monthly runoff was agreed upon for the conduct of water resource studies within the framework of the 'Proyecto Centroamericano de Cambio Climático'(PCCC; Central-American Climate Change Study). However, in the case of Panama, it was necessary to have this period reduced to $10 \mathrm{yr}$ for the Chiriquí and La Villa river basins due to the lack of complete temperature records prior to 1973 , needed for estimating potential evapotranspiration values.

Records from 48 precipitation stations were used for the study, which were distributed as follows: 21 at the Chagres river basin, 17 at the Chiriquí and 10 at the La Villa. The number of stations was deemed sufficient, considering the size of each basin and the spatial variability of this parameter.

However, in all 3 basins there are fewer stations having temperature records for the study period than required. In fact, there is only 1 station in both the Chagres and La Villa river basins, located at 20 and $16 \mathrm{~m}$ above mean sea level respectively. The Chiriquí river basin has 4 such stations, located between 388 and $1340 \mathrm{~m}$ above mean sea level.

Information on river flow was obtained directly from gauging stations, except for the Chagres river basin. In this case, the daily discharges to Gatún Lake estimated on the basis of the water balance were used (Table 1).

Central American experts have analyzed several general circulation models (GCMs) for the development of climatic scenarios, namely the CCCM, UK86,
UK89, GISS, GFDL-R30 and GFDL 1\% (transient). Their assessment of the models' ability to reproduce current climate conditions has led to the conclusion that, in general, GCMs are not a highly reliable tool for studies in this region. Further, since water resource studies are carried out at a much smaller scale than are the GCMs, the direct use of GCM outputs in the water resource simulations is not considered appropriate. Thus, the CCCM and UK89 models, which are the ones that in general terms best simulate the current climate in the Central American region, were only taken into account as a reference.

Due to the above considerations regarding GCM outputs and analogies, the use of conservative scenarios with incremental increases in temperature and incremental changes in precipitation was preferred instead. This decision was based particularly on findings by IPCC Working Group I presented in the report by the OMM/PNUMA (1995), which acknowledge the weaknesses of GCMs for the simulation of regional climate. Incremental scenarios based on expert judgement were consequently developed.

\section{METHODOLOGY}

2.1. Model description. The rainfall-runoff hydrological model CLIRUN3 (Kaczmarek 1994) was used to estimate the impacts of climate change on water resources. The theoretical basis of this conceptual, global model was developed at the International Institute for Applied Systems Analysis and at the Institute of Geophysics, Warsaw, Poland. It is based on the fundamental hydrology theorem:

$$
P=P E T+Q
$$

where $\mathrm{P}=$ mean precipitation $\left(\mathrm{mm} \mathrm{d}^{-1}\right)$, PET $=$ potential evapotranspiration $\left(\mathrm{mm} \mathrm{d}^{-1}\right)$ and $Q=$ mean values of catchment runoff $\left(\mathrm{mm} \mathrm{d}^{-1}\right)$.

Input data for this model are the effective precipitation, potential evapotranspiration and historical river flow data. The output data simulate the response of the basin in terms of surface runoff as well as changes in storage and evapotranspiration.

Table 1. Hydrological gauging stations at each basin

\begin{tabular}{|c|c|c|c|c|c|c|}
\hline Basin & Base station & $\begin{array}{l}\text { No. of years } \\
\text { with records }\end{array}$ & $\begin{array}{l}\text { Area upstream } \\
\text { of gauging } \\
\text { station } \\
\left(\mathrm{km}^{2}\right)\end{array}$ & $\begin{array}{c}\text { Total area } \\
\left(\mathrm{km}^{2}\right)\end{array}$ & $\begin{array}{l}\text { Mean altitude } \\
\text { (upstreàm of } \\
\text { gauging station) } \\
\text { (m) }\end{array}$ & $\begin{array}{c}\% \text { of study } \\
\text { area }\end{array}$ \\
\hline Chiriquí & Interamericana & 40 & 1337 & 1995 & 640 & 67 \\
\hline Chagres & (Discharges to Gatún Lake) & 80 & 3338 & 3338 & 75 & 100 \\
\hline La Villa & Atalayita & 30 & 1000 & 1284 & 180 & 78 \\
\hline
\end{tabular}




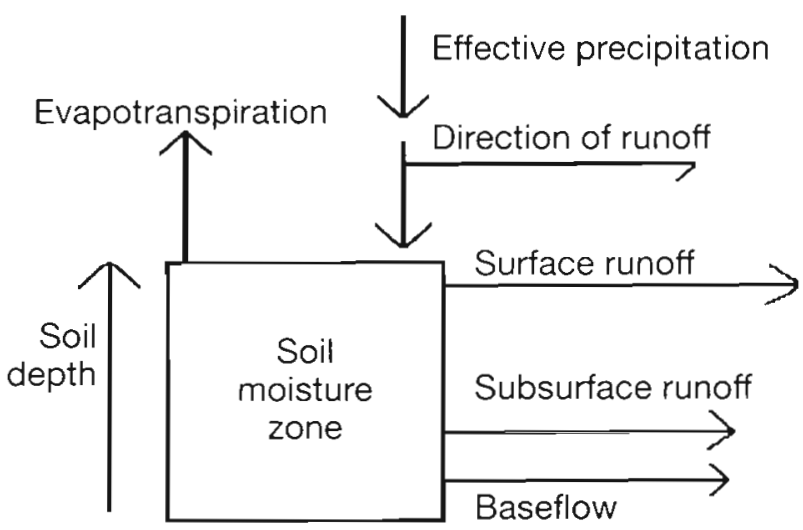

Fig. 1. Conceptual description of water balance for the water balance model

The model is continuous, which means that the variables in the water balance equation are a function of the time interval used. In this particular case the model was calibrated with a 1 mo time interval. In the CLIRUN3 version used, the input variables (climatic variables) were considered representative of the entire basin.

The model has 2 components: the first one calculates the water balance in the basin using continuous functions which describe the inflow and outflow, while the second one calculates potential evapotranspiration by means of the Priestly-Taylor method, which is based on radiation. In this study only the first component was used.

The water balance is written as a differential equation and the basin storage is considered to be a single 'bucket', where the discharge and infiltration components are dependent on the state variables (Fig. 1).

The model has 5 parameters, 3 of which are changed by the automatic calibration routine. These parameters are related to: (1) direct runoff, (2) surface runoff, (3) and (4) subsurface runoff, and (5) storage capacity.

The model is calibrated using a non-confined inductive algorithm which seeks the optimum set of model parameters, estimated on the basis of error minimization between observed and simulated monthly runoff data by means of the method of least squares. The direct runoff coefficient and the power term of the subsurface runoff are not included in the optimization routine.

The measured flow data for the dry months (March and April) of the entire record were used to determine the base flow at each station, which is an important input parameter for the model. Probability tests were used to calculate the flow value which is equaled or exceeded $95 \%$ of the time. The minimum flows were estimated at $1.38,0.20$ and $0.21 \mathrm{~mm} \mathrm{~d}^{-1}$ for the Chiriquí, La Villa and Chagres river basins respectively.
The effective precipitation is a measure of the rainfall which actually becomes surface runoff. For the purposes of this study the effective precipitation was considered equal to the precipitation measured at each station, since it is assumed that in the tropical regions the losses due to surface holding are minimal compared to total rainfall volumes. The average precipitation at each basin was estimated by means of the Thiessen polygons method (Chow at al. 1993).

Statistical analyses (mean and standard deviation tests, linear correlation, tests of relative differences and range tests) were applied for assessing the consistency of the series simulated during calibration and validation. Linear correlation was applied in order to generate the missing data on precipitation and river flows. The double mass curve method was used to verify the series (Linsley at al. 1977).

The mean monthly potential evapotranspiration for the 3 basins was estimated with the Thornthwaite method and adjusted with Penman values, as described in the study reported in Hidrometeorología (1993).

The Thornthwaite method (described by Ortiz Solorio 1984) calculates potential evapotranspiration from mean annual temperature values. The values are corrected as a function of latitude, implicitly considering the theoretical sunshine hours.

The Penman method (WMO 1994) is the most complete, since it takes into account the majority of the factors which determine evapotranspiration, namely energy supply and vapor transport. This method has been widely used with very good results, although in arid regions the values are usually underestimated.

An equation from the study by Ortiz Solorio (1984) was used with some modifications in the above mentioned study given in Hidrometeorología (1993). In particular, the coefficients of the Armstrong equation (0.26 and 0.39 ) were estimated by means of linear correlation between the $R g / R a$ and $N / n$ ratios, where $R g$ is the total solar radiation, $R a$ is the theoretical solar radiation in absence of atmosphere, $N$ is the maximum theoretical sunshine hours and $n$ is the actual sunshine hours.

$$
R g / R a=0.26+0.39 n / \mathbb{N}
$$

The meteorological parameters used in this equation are: relative humidity, actual sunshine hours, wind speed $\left(\mathrm{m} \mathrm{s}^{-1}\right)$ at an elevation of $2 \mathrm{~m}$, and air temperature. The remaining parameters are estimated as a function of elevation and temperature.

The Penman method was not directly applied because it requires climatic information which is only measured at type A (complete) stations, of which there are only 7 in Panama.

The Thornthwaite method, which is based only on temperature, usually underestimates values and pro- 
duces fairly homogeneous results throughout the year. Since this is inconsistent with the monthly variations in the measured Pan A (Evaporation tank-class $A$; it has a cylindrical shape: $25.4 \mathrm{~cm}$ deep and $120.67 \mathrm{~cm}$ diameter) transpiration values, the estimates had to be adjusted.

Two correlation equations were obtained for that purpose: one for the dry season ( $\mathrm{r}=0.92)$ and another one for the wet season ( $r=0.89$ ). This was done by correlating the monthly potential evapotranspiration values estimated with both methods above for the 7 weather stations having complete data series (WMO 1985). A 20 yr period was considered (1963 to 1982)

Few stations have temperature records available for this period and most of them are located in the low part of the basin. Therefore, the monthly potential evapotranspiration series obtained was adjusted once again using altitude and temperature equations as well as the mean elevation value of each basin in order to make it representative of the entire basin.

2.2. Calibration of CLIRUN3. The study period covered 10 yr (1973 to 1982) for the Chiriquí and La Villa river basins, and 20 yr (1963 to 1982) for the Chagres river basin. Model calibration was performed with $50 \%$ of the available data, while the remaining $50 \%$ were used for model validation.

Land use is fairly similar in the basins studied, since, except in the case of the Chagres, they are characterized by important agricultural activities. Therefore the vegetation consists of sabanas, crops and secondary native vegetation. The soils are mostly erosive lithosols and latosols. Based on these conditions and on the relative characteristics of the measured runoff, it was established that the variations in the maximum storage capacity (SMAX) for model calibration should not exceed $500 \mathrm{~mm}$, and that the initial water holding capacity values would range between 0.63 and 0.8 .

The initial SMAX value for calibration was the same for all 3 basins (SMAX = 25). The initial water holding capacity and base flow values were different according to the conditions at each basin. $\varepsilon$ (power term of the surface runoff expression) and $\alpha$ (coefficient in front of the subsurface runoff expression) were the independent variables.

The preliminary calibration process was intended to stabilize SMAX and the objective function (OF). The stabilized SMAX thus obtained is considered representative of the storage conditions in each case. This first calibration and validation effort resulted in high correlation coefficients, with a
Table 2. Calibration values used for CLIRUN3 in this study

\begin{tabular}{|lccccc|}
\hline Basin & $\begin{array}{c}\text { Stabilization } \\
\text { iteration }\end{array}$ & $\alpha$ & $\varepsilon$ & SMAX & $\begin{array}{c}\text { Objective } \\
\text { function }\end{array}$ \\
\hline Chiriquí & 9 & 4.38 & 0.108 & 479.0 & 269.90 \\
La Villa & 8 & 1.94 & 0.05 & 430.0 & 60.00 \\
Chagres & 9 & 2.04 & 0.22 & 437.0 & 67.00 \\
\hline
\end{tabular}

good fitting of the data according to the statistical tests applied. However, the simulated values corresponding to the dry season were far below the real values. In addition, the dry season had an early start and the simulated values corresponding to the end of this season (March and April) were, in all cases, higher than the measured values. For this reason a new calibration was carried out in order to obtain simulated values for the dry season (which is the most critical period) with a better fit to measured values. The stabilization of parameters was not performed, except for SMAX, which was adjusted to real storage conditions in the basins. As shown in Table 2, SMAX stabilization was achieved at iterations 8 and 9 .

Simulations were performed under 4 incremental scenarios for each basin. For the Pacific basins (La Villa and Chiriquí) an increase in temperature of $+1^{\circ} \mathrm{C}$ and $+2{ }^{\circ} \mathrm{C}$ combined with $\pm 15 \%$ and $\pm 10 \%$ changes in precipitation were considered. In the case of the Chagres basin (Atlantic) the increments used were of $+2^{\circ} \mathrm{C}$ in temperature and $\pm 10 \%$ and $\pm 20 \%$ for precipitation.

The selection of the above scenarios was performed taking into account several criteria, namely basic considerations on regional climate and information provided by the Central American Hydrometeorological Services (140 hydrometeorological stations), the judgement of experts, Köppen's classification of cli-

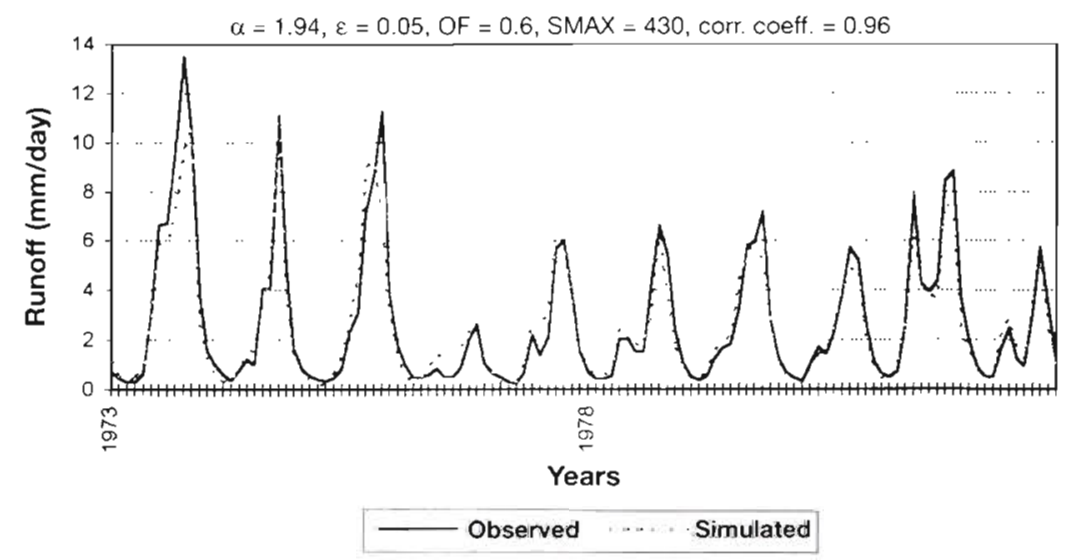

Fig. 2. Comparison of observed and simulated monthly water flows, La Villa river basin, 1973 to 1982 
mate, and the use of the watershed as a basic study unit.

Different scenarios were considered for each watershed, since these watersheds are characterized by different precipitation patterns. The region of the Caribbean watershed is more rainy and cloudy than the Pacific region. Therefore, the highest temperatures occur in the Pacific region. In addition, the prevailing winds (trade winds) which blow from the Pacific to the Caribbean are exposed to an adiabatic compression effect.

\section{RESULTS AND DISCUSSION}

The CLIRUN3 model provides a very good simulation of runoff. In all cases the correlation coefficient between the mean monthly flow of the simulated and the measured series is higher than 0.95 , both during calibration and validation (Figs. 2 , $3 \& 4)$.

Correlation coefficients between observed and simulated monthly water flow values are also higher than 0.91 if the values are classified into dry and wet seasons (Table 3).

Good consistency in the means and standard deviation for all basins with regard to the observed and simulated data of the series used for calibration and validation was found using statistical tests (mean and standard deviation, with a confidence level of $95 \%$ ).

Simulations under the different incremental scenarios for the 3 basins indicate that the river flows are affected differently with changes in the temperature and precipitation patterns. The basins located on the Pacific watershed (Chiriquí and La Villa) are the most critically affected. An increase in temperature $\left(+1^{\circ} \mathrm{C}\right.$ and $\left.+2^{\circ} \mathrm{C}\right)$ causes a river flow reduction of 5 to $35 \%$ during the dry season, independently of an increase $(+10 \%,+15 \%)$ or decrease $(-10 \%,-15 \%)$ in precipitation. Under the conditions of the most critical scenario $\left(+2^{\circ} \mathrm{C}\right.$ and $-20 \%$ precipitation in the Atlantic, and $+2^{\circ} \mathrm{C}$ and $-15 \%$ precipitation in the Pacific) the mean annual flow decreases by $24 \%$ in Chiriquí river basin, $26 \%$ in the Chagres basin and $35 \%$ in the La Villa basin (Tables $4,5, \& 6$ ).

One of the limitations of this study was the lack of meteorological data, such as radiation, wind speed and relative humidity, at the national level. This is a con-

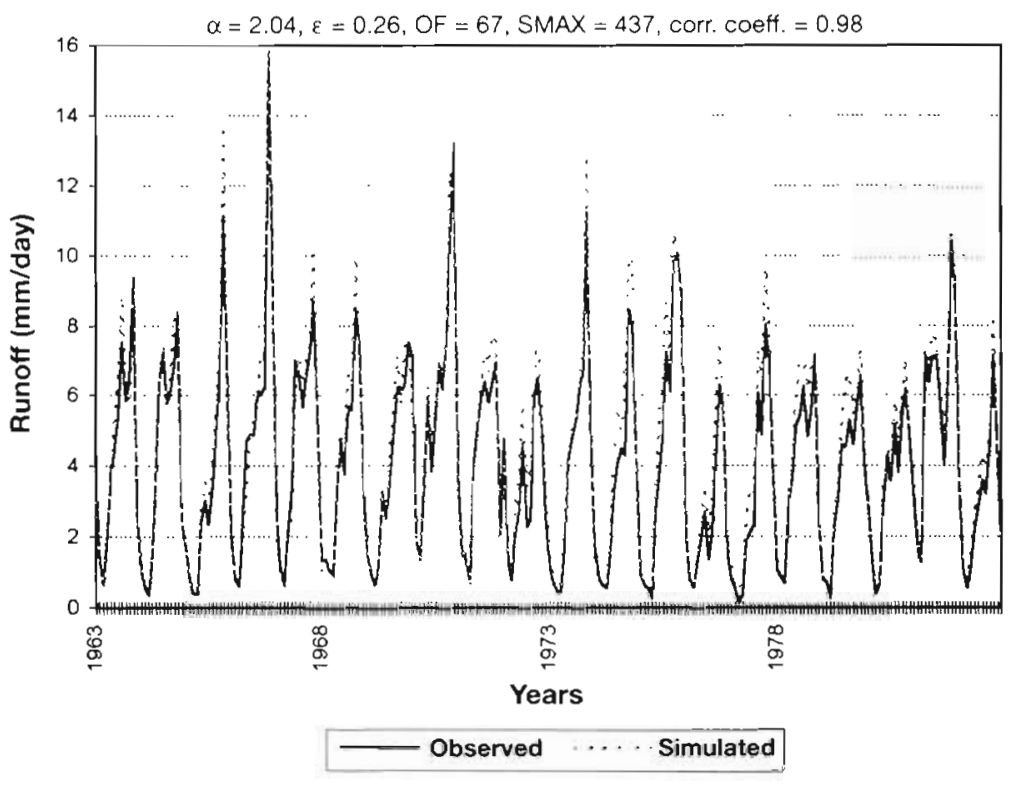

Fig. 3. Comparison of observed and simulated monthly water flows, Chagres river basin, 1963 to 1982

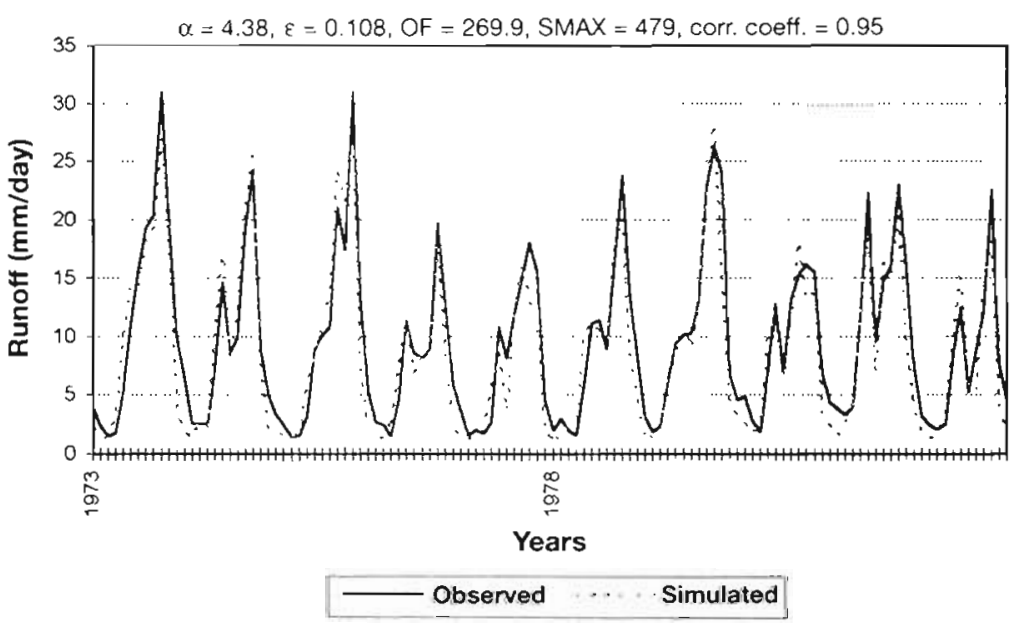

Fig. 4. Comparison of observed and simulated monthly water flows, Chiriquí river basin, 1973 to 1982

Table 3. Correlation coefficients between observed and simulated river flows (dry and wet seasons)

\begin{tabular}{|llc|}
\hline River basin & Season & Correlation coefficient \\
\hline Chiriquí & Wet & 0.91 \\
& Dry & 0.94 \\
La Villa & Wet & 0.96 \\
& Dry & 0.95 \\
Chagres & Wet & 0.96 \\
& Dry & 0.99 \\
\hline
\end{tabular}


Table 4. Chagres river basin: monthly water resource availability (river flow) under various climate scenarios. P: precipitation; diff.: difference

\begin{tabular}{|c|c|c|c|c|c|c|c|c|c|}
\hline \multirow[t]{3}{*}{ Month } & \multirow[t]{3}{*}{$\begin{array}{l}\text { Observed flow } \\
\qquad\left(\mathrm{mm} \mathrm{d}^{-1}\right)\end{array}$} & \multicolumn{4}{|c|}{$\begin{array}{l}\text { Temperature and precipitation } \\
\text { increase scenarios }\end{array}$} & \multicolumn{4}{|c|}{$\begin{array}{l}\text { Temperature increase and } \\
\text { precipitation decrease scenarios }\end{array}$} \\
\hline & & \multicolumn{2}{|c|}{$+2^{\circ} \mathrm{C}$ and $+20 \% \mathrm{P}$} & \multicolumn{2}{|c|}{$+2^{\circ} \mathrm{C}$ and $+10 \% \mathrm{P}$} & \multicolumn{2}{|c|}{$+2^{\circ} \mathrm{C}$ and $-20 \% \mathrm{P}$} & \multicolumn{2}{|c|}{$+2^{\circ} \mathrm{C}$ and $-10 \% \mathrm{P}$} \\
\hline & & Simulated & $\%$ diff. & Simulated & $\%$ diff. & Simulated & $\%$ diff. & Simulated & $\%$ diff. \\
\hline $\operatorname{Jan}$ & 2.41 & 2.49 & 3 & 2.29 & -5 & 1.65 & -32 & 1.87 & -22 \\
\hline Feb & 1.05 & 1.13 & 8 & 1.05 & 0 & 0.79 & -25 & 0.88 & -16 \\
\hline Mar & 0.67 & 0.77 & 15 & 0.72 & 7 & 0.55 & -18 & 0.60 & -10 \\
\hline Apr & 1.65 & 2.00 & 21 & 1.79 & 8 & 1.22 & -26 & 1.40 & -15 \\
\hline May & 3.28 & 4.40 & 34 & 3.85 & 17 & 2.44 & -26 & 2.87 & -12 \\
\hline Jun & 4.33 & 6.18 & 43 & 5.33 & 23 & 3.17 & -27 & 3.82 & -12 \\
\hline Jul & 4.48 & 6.67 & 49 & 5.80 & 29 & 3.44 & -23 & 4.17 & -7 \\
\hline Aug & 5.3 & 7.50 & 42 & 6.57 & 24 & 3.95 & -25 & 4.78 & -10 \\
\hline Sep & 5.38 & 7.60 & 41 & 6.69 & 24 & 4.09 & -24 & 4.92 & -9 \\
\hline Oct & 6.91 & 9.45 & 37 & 8.33 & 21 & 5.08 & -26 & 6.13 & -11 \\
\hline Nov & 8.3 & 11.03 & 33 & 9.79 & 18 & 6.10 & -27 & 7.32 & -12 \\
\hline Dec & 4.93 & 5.68 & 15 & 5.14 & 4 & 3.46 & -30 & 4.03 & -18 \\
\hline Average & 4.06 & 5.41 & 28 & 4.78 & 14 & 3.00 & -26 & 3.57 & -13 \\
\hline
\end{tabular}

Table 5. Chiriquí river basin: monthly water resource availability (river flow) under various climate scenarios. P: precipitation; diff.: difference

\begin{tabular}{|c|c|c|c|c|c|c|c|c|c|}
\hline \multirow[t]{3}{*}{ Month } & \multirow[t]{3}{*}{$\begin{array}{l}\text { Observed flow } \\
\left(\mathrm{mm} \mathrm{d}^{-1}\right)\end{array}$} & \multicolumn{4}{|c|}{$\begin{array}{c}\text { Temperature and precipitation } \\
\text { increase scenarios }\end{array}$} & \multicolumn{4}{|c|}{$\begin{array}{l}\text { Temperature increase and } \\
\text { precipitation decrease scenarios }\end{array}$} \\
\hline & & \multicolumn{2}{|c|}{$+2^{\circ} \mathrm{C}$ and $+15 \% \mathrm{P}$} & \multicolumn{2}{|c|}{$+1^{\circ} \mathrm{C}$ and $+10 \% \mathrm{P}$} & \multicolumn{2}{|c|}{$+2^{\circ} \mathrm{C}$ and $-15 \% \mathrm{P}$} & \multicolumn{2}{|c|}{$+1^{\circ} \mathrm{C}$ and $-10 \% \mathrm{P}$} \\
\hline & & Simulated & $\%$ diff & Simulated & $\%$ diff. & Simulated & $\%$ diff. & Simulated & $\%$ diff \\
\hline Jan & 4.03 & 3.34 & -17 & 3.32 & -18 & 2.86 & -29 & 3.00 & -26 \\
\hline Feb & 2.8 & 2.35 & -16 & 2.35 & -16 & 2.04 & -27 & 2.14 & -24 \\
\hline Mar & 2.27 & 2.16 & -5 & 2.15 & -5 & 1.84 & -19 & 1.93 & -15 \\
\hline Apr & 2.54 & 3 & 18 & 2.95 & 16 & 2.3 & -9 & 2.46 & -3 \\
\hline May & 6.58 & 9.23 & 40 & 8.74 & 33 & 5.38 & -18 & 6.08 & -8 \\
\hline Jun & 12.55 & 15.44 & 23 & 14.69 & 17 & 9.34 & -26 & 10.59 & -16 \\
\hline Jul & 9.44 & 10.18 & 8 & 9.83 & 4 & 7.17 & -24 & 7.82 & -17 \\
\hline Aug & 11.89 & 13.59 & 14 & 13.01 & 9 & 9.05 & -24 & 9.98 & -16 \\
\hline Sep & 16.77 & 20.41 & 22 & 19.51 & 16 & 13.73 & -18 & 15.07 & -10 \\
\hline Oct & 22.23 & 23.88 & 7 & 22.86 & 3 & 16.72 & -25 & 18.1 & -19 \\
\hline Nov & 16.44 & 14.34 & -13 & 13.81 & -16 & 10.53 & -36 & 11.26 & -32 \\
\hline Dec & 7.27 & 5.5 & -24 & 5.4 & -26 & 4.54 & -38 & 4.76 & -35 \\
\hline Average & 9.57 & 10.29 & 5 & 9.89 & 2 & 7.13 & -24 & 7.77 & -18 \\
\hline
\end{tabular}

straint for the use of methodologies developed in other regions, particularly with regard to the estimation of a monthly series of potential evapotranspiration values representative of a basin. This parameter has a considerable influence on the study results. Therefore, it became necessary to develop methodologies which could be applied under such limitations.

Another difficulty encountered during the study was the impossibility of directly introducing the evaporation measured at the lakes into the calculations. In the case of the Chagres river basin, losses due to evaporation are significant, representing about $15 \%$ of the total inflow. It was therefore necessary to include them in the potential evapotranspiration series with a value proportional to the area of the basin.

\section{CONCLUSIONS}

In spite of the deficiencies with regard to the availability of temperature and radiation data, the CLIRUN3 model simulations provide a well-fitted representation of the observed river flows. The correlation coefficients between simulated and observed values in the 3 basins studied are higher than 0.9 , both with respect to calibration and validation. 
Table 6. La Villa river basin: monthly water resource availability (river flow) under various climate scenarios. P: precipitation; diff.. difference

\begin{tabular}{|c|c|c|c|c|c|c|c|c|c|}
\hline \multirow[t]{2}{*}{ Month } & \multirow[t]{2}{*}{$\begin{array}{l}\text { Observed flow } \\
\left(\mathrm{mm} \mathrm{d} \mathrm{d}^{-1}\right)\end{array}$} & \multicolumn{4}{|c|}{$\begin{array}{c}\text { Temperature and precipitation } \\
\text { increase scenarios }\end{array}$} & \multicolumn{4}{|c|}{$\begin{array}{l}\text { Temperature increase and } \\
\text { precipitation decrease scenarios }\end{array}$} \\
\hline & & $\begin{array}{l}+2^{\circ} \mathrm{C} \text { and } \\
\text { Simulated }\end{array}$ & $\begin{array}{l}+15 \% \mathrm{P} \\
\% \text { diff. }\end{array}$ & $\begin{array}{l}+1^{\circ} \mathrm{C} \text { anc } \\
\text { Simulated }\end{array}$ & $\begin{array}{l}+10 \% \mathrm{P} \\
\% \text { diff. }\end{array}$ & $\begin{array}{l}+2^{\circ} \mathrm{C} \text { and } \\
\text { Simulated }\end{array}$ & $\begin{array}{l}-15 \% \mathrm{P} \\
\% \text { diff. }\end{array}$ & $\begin{array}{l}+1^{\circ} \mathrm{C} \text { an } \\
\text { Simulated }\end{array}$ & $\begin{aligned}-10 \% \mathrm{P} \\
\% \text { diff. }\end{aligned}$ \\
\hline Jan & 1.18 & 0.90 & -24 & 0.94 & -20 & 0.77 & -35 & 0.85 & -28 \\
\hline Feb & 0.68 & 0.44 & -35 & 0.48 & -29 & 0.39 & -43 & 0.45 & -34 \\
\hline Mar & 0.44 & 0.3 & -32 & 0.32 & -27 & 0.27 & -39 & 0.3 & -32 \\
\hline Apr & 0.45 & 0.48 & 7 & 0.49 & 9 & 0.38 & -16 & 0.42 & -7 \\
\hline May & 1.17 & 1.49 & 27 & 1.47 & 26 & 0.92 & -21 & 1.06 & -9 \\
\hline Jun & 2.4 & 2.78 & 16 & 2.71 & 13 & 1.44 & -40 & 1.74 & -27 \\
\hline Jul & 2.21 & 2.82 & 28 & 2.76 & 25 & 1.52 & -31 & 1.83 & -17 \\
\hline Aug & 2.86 & 3.78 & 32 & 3.69 & 29 & 1.95 & -32 & 2.38 & -17 \\
\hline Sep & 4.89 & 5.75 & 18 & 5.62 & 15 & 2.94 & -40 & 3.65 & -25 \\
\hline Oct & 7.38 & 7.94 & 8 & 7.71 & 4 & 4.38 & -41 & 5.32 & -28 \\
\hline Nov & 6.32 & 5.71 & -10 & 5.58 & -12 & 3.66 & -42 & 4.22 & -33 \\
\hline Dec & 2.5 & 1.92 & -23 & 1.93 & -23 & 1.5 & -40 & 1.66 & -34 \\
\hline Average & 2.71 & 2.86 & 1 & 2.81 & 1 & 1.68 & -35 & 1.99 & -24 \\
\hline
\end{tabular}

The results of the river flow simulations indicate that the basins located in the Pacific region would be the most affected under the conditions of the incremental scenarios considered in this study. During the months with a higher water demand, which occur in the dry season (November to April), there would be a decrease in flow associated with a temperature increase, irrespective of whether the precipitation increases or decreases. This suggests a high sensitivity of the basins to changes in temperature, particularly during the dry season.

Under a scenario of increase in temperature and decrease in precipitation, the mean monthly flow tends to decrease by 3 to $42 \%$ both in the Atlantic and Pacific basins.

If simultaneous increases in temperature and precipitation took place, the flow in the Pacific basins would be reduced (by 5 to $35 \%$ ) from November to March. During the remaining months the mean flow would increase by 4 to $40 \%$. However, in the basin of the Atlantic watershed all the simulated values would be 3 to $50 \%$ higher than the mean value.

There exists a great uncertainty in the assessment of changes in climatic conditions for different time periods due to the fact that GCMs are not a highly reliable tool for studies in the Central American region. However, the use of incremental scenarios allow us to evaluate the degree of sensitivity of water resource availability under different temperature increments and precipitation changes.

Acknowledgements. The authors acknowledge engineers Carlos Vargas and Jorge Espinosa, of the Meteorological and Hydrographic Branch of the Panama Canal Commission, for their valuable support in providing hydrometeorological information recorded at the Panama Canal basin. We also thank the staff of the Hydrometeorology Departament of the IRHE for their assistance in the preparation of this report. This study was carried out at the Departamento de Hidrometeorología, Sección de Hidrología of the Instituto de Recursos Hidráulicos y Electrificación (public entity). It was sponsored by the Comisión Centroamericana de Ambiente y Desarrollo (CCAD) and the Comité Regional de Recursos Hidráulicos (CRRH) and supported by the U.S. Government through the U.S. Country Studies Program. within the framework of the Proyecto Centroamericano sobre Cambio Climático (PCCC; Central-American Climate Change Study).

\section{LITERATURE CITED}

Chow VT, Maidment DR, Mays LW (1993) Applied hydrology. McGraw-Hill, New York

Hidrometeorología (1993) Evaluación de la evapotranspiración potencial para la República de Panamá. IRHE, Panama City

Kaczmarek Z (1994) Climate run-off model CLIRUN3: user guide. Polish Academy of Sciences, Institute of Geophysics, Warsaw

Linsley R, Kohler M, Paulus J (1977) Hidrología para Ingenieros, 2nd edn. McGraw-Hill, New York

OMM/PNUMA (Organización Meteorológica Mundial/Programa de las Naciones Unidas para el Medio Ambiente) (1995) Cambio climático: evaluación científica del IPCC. Versión en español del Instituto Nacional de Meteorología de España, Madrid

Ortiz Solorio CA (1984) Elementos de agrometeorología cuantitativa con aplicaciones en la República Mexicana. Imprenta Universitaria, Universidad Autónoma de Chapingo

WMO (World Meteorological Organization) (1985) Casebook on operational assessment of areal evaporation. WMO Publ No. 635, Geneva

WMO (World Meteorological Organization) (1994) Estimating basin evapotranspiration: guide to hydrological practices. WMO Publ No. 168, Geneva 